\title{
Challenges and Responses of Higher Education institutions to align higher Education with COVID-19 Realities: A Thematic Analysis
}

\author{
Dr Sajid Ali Yousuf Zai \\ Assistant Professor \\ Department of Education, NUML \\ sayousuf@numl.edu.pk \\ Aisha Shams Akhunzada \\ Ph.D. Student \\ Department of Education, FJWU Rawalpindi
}

\begin{abstract}
The world is in the fright condition and facing the threat of COVID-19 and Pakistan is not an exceptional in this situation. By the decision of National Command and Operation Centre (NCOC), all the universities and institutions were closed for formal academic activities and starting online classes from March, 2020. This was an astounding paradigm for the regular students of the institutions as well as for the faculty. Hence, this study has been conceded to find out what the faculty and students got what they lost individually and scholastically and what are their suggestions for the improvement and uniformity of the online learning system throughout the country. The purpose of this study was to explore the role of HEC during COVID-19 to implement the immediate online learning and its impact on students learning. This research was based on qualitative research in which data were collected from the literature available online. Various contemporary articles, papers, reports, blogs, newspaper reports as well official reports and news were carried out into consideration for this study. However, the thematic method was used for categorization of the main themes from the literature related to the views of the students and faculty and the role of HEC in the improvement of the online teaching-learning process in Pakistan. Recommendations for the improvement of online teaching and learning system were proposed in the light of current pandemic situation.
\end{abstract}

Keywords: COVID-19, online learning, thematic analysis, challenges and responses, higher education, HEC Role.

\section{Introduction}

Corona virus has a history since 1960, conversely, its toxicities were perceived for the first time in 2002-03. COVID-19 (CO from Corona, VI from Virus, and Dr from Dieses, 19 from 2019) name was given by the WHO (World Health Organization) on February, 2020 for the disease caused by the novel corona virus SARS-CoV-2 (Vergnaud, 2020). It was started from Chinese city Wuhan in December 2019 and has since spread whole world. Consequently, Pakistan being a close 
neighbor country to china and Iran correspondingly caused through COVID-19. The first case of COVID-19 was reported on 25 February, 2020 and the first death was reported on 29 March, 2020. There was less seriousness on corona virus during that period. Most of the people had the opinion that the COVID-19 is just a hoax, while some people thoughts that it is an conspiracy by strongest people in this world. On the other hand, hardly few people believed that it is real and people got infected through this virus. Various countries' government took immediate actions to safeguard their people. Similarly, government of Pakistan established National Command and Operation Centre (NCOC), a concertized body to keep an eye on the pandemic and take whatever actions needed for the safety of people.

To avoid the rapid spread of corona virus, the NCOC recommended that all schools, colleges, and universities throughout the country should be closed from March 13, 2020. This act of government was initially criticized for the reasons that no alternative plans such as online classes, quiz programs, reading materials, and assignments were made to save the students' time. But with time it has been proved that the closure was justified and that it was a good decision (Nafees \& Khan, 2020).

Online education is an accepted norm because the academy can adapt permanently to this new paradigm (Massan et al., 2020).Digital devices such as a computer, tablet, or a smart-phone have become the sources of stipulation rather than luxuries. The arrangement of scholarships or student loans by the universities has become the requirement so the needy students can get benefit from online learning. Universities must make such a prerequisite, and arrange scholarships or student loans for those who cannot afford so to allow them to do so. HEC recommended that as the member of the society, universities should ensure the availability of all the sources of knowledge to each student (HEC, 2020).

Education is significant to realization and this field needs a birds-eye for elevating all the other fields. Research work has been done in many other fields specified in the field of biology. Yet diminutive work has been done in the field of education. Therefore, this study has been conducted to contribute to the field of education during COVID-19.

\subsection{Objectives of the Study}

1. To explore the positive aspects of the online system from the prospective of students and faculty. 
2. To identify challenges of the online teaching learning system for students and faculty.

3. To analyze the role of HEC in the improvement of the online teaching-learning process during COVID-19.

4. To propose themes for the improvement and uniformity of the online learning system throughout the country.

\subsection{Significance of the Study}

The study will contribute the students, instructors, and policymakers for updating the collaborative learning through online system. This study will help for cooperation among teachers, students, and the policymakers specifically HEC. This study will aware of the readers about the problems and suggestions for the improvement of online mode of teaching and learning. Moreover, this study will open new era for researchers to explorer further on this field.

\section{Literature Review}

The literature review is comprised of five parts. The first part describes the facts and reality about the outbreak of COVID-19 and the beginning of digital learning. Moreover, the gains or pros, loss or cons of online learning for the regular learners and the faculty members include in the second as well as in the third part. Indispensable rations for the advancement of online learning correspondingly described in the subsequent part of the literature. The role of HEC, students, and faculty members in the improvement of online learning is additionally described in this section.

\subsection{The Outbreak of COVID-19 and Online Learning}

Pandemic is a word that has been derived from the two Greek words pan(all)and demo(people),and this is the term used by the experts from the medical field when epidemics are increasing simultaneously in the world. The WHO represents the term 'an outbreak of a new pathogen that effectively circulates throughout the world from individual to individual' (Newey \& White, 2020).

Around December 2019, the incidence of the new corona virus disease emerged throughout China (Wuhan), and also has particularly drawn national and international attention. Through February 9, 2020, there had been 37,294 reported incidents of corona virus epidemic (COVID-19) in China and 28,942 suspected cases (Chen et al., 2020). Additionally, the official declared cases 
were recorded on 19 February in the Qom region, Iran, beginning in December 2019 from China. As of April 3, 2020, a total of 932,166 cases were registered in 206 countries with 46,764 deaths. Iran has endured the most extreme burden of COVID-19 outbreak besides China, the USA, Italy, Spain, and Germany (Raoofi et al., 2020). During COVID-19 different online psychological services were reprocessed in China. Likewise, online psychological therapy services (e.g. WeChatbased resources) were progressively developed by Psychosocial practitioners in health care schools, colleges and higher education associations across all 31 provinces and throughout the country which provide twenty-four-hour treatment on all weekdays (Liu et al., 2020). The online courses have been the backbone of modern higher education since the coronavirus outbreak. Besides the classes have been shifted to online mode by the educational institutions however different methods are still under consideration by the instructors for engaging students online ("The Rise of Online Classes after COVID-19: Best Practices Based on Literature", 2020).

Pakistan is currently witnessing the second re-emergence of its education market (Massan et al., 2020).Moreover, Massanetal cited Siddique,2020 that Pakistan's universities have welladjusted to the shifting paradigm of 'flipping the classes' this phrase was coined by Salman Khan of the world-renowned Khan academy. The model of online classes has been embraced across the country and high-quality teaching is carried out at all major universities throughout the world. Meanwhile, one of Pakistani University, decided to take online courses on either a self-help basis on their own. While referring to one journalist, teachers said it was the first all they had to do was creating a group chat of WhatsApp, whereby teachers linked related students of different courses, and continued to give multimedia tutorials. Moreover, they said that "We set one an hour for every student in the class and provide the relevant material to the students, except for lectures and question-answer sessions (Khushik,2020).

Higher Education Institutions (HEIs) in Pakistan were allowed by the HEC for conducting online education if and only if following six key components are ready and ensured by the vicechancellors of HEIs. 


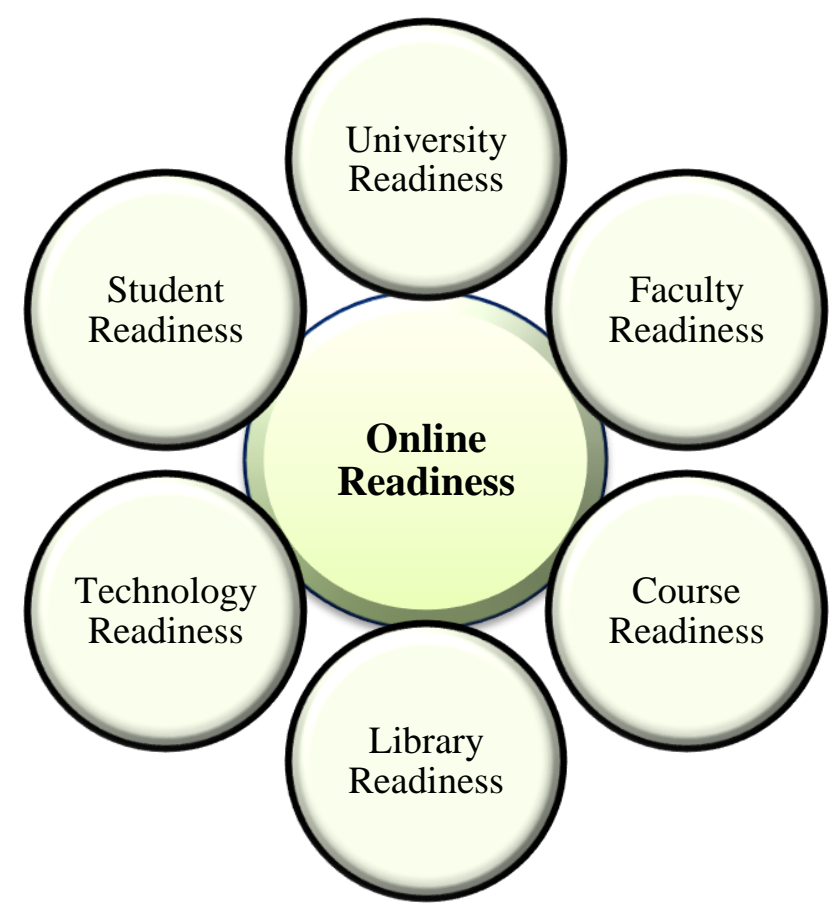

Figure 1: Six Elements for Online Classes (HEC Announcements, 2020).

\subsection{Pros of Online Learning}

Covid-19 condition is expected to irreversibly affect education but the results are still too early to detect. Nonetheless, the large number of students and academic staff can make successful use of their reserves, proceed mostly with learning effort. Like all the others, they have concerns, however, desire to resolve the objections and discover practical and strategic alternatives (HEC, 2020).

Khalid (2020) quoted the statement of Assistant Professor, "they wouldn't waste their time unless learners became able to get online so they could know more while at home". The aforementioned studies have presented that online learning is an active learning, migrating away from the concept of traditional tutorials, often using engaging teaching strategies, incorporating activities like conceptualization, idea generation, research, visualization, and student-centered teaching-learning process (Zayapragassarazan \& Kumar,2012).Fortunately, past research established a strong correlation whatsoever between internet-based learning, learner's engagement, and studying consequences (Kahn, Everington, Kelm, Reid, \& Watkins, 2017). Consequently, online courses make the curriculum more accessible, making a higher curriculum 
more inclusive in effect. Many students, especially adult or school learners, required stability into their deadlines and program selections to attend class (Moore, \& Greenland, 2017).

Likewise, online classes offer students from historically disadvantaged communities the opportunity to participate. Research found where learners are first to study at the tertiary level in their communities, individuals having low socio and economic background and with special needs certainly learn from both the expansion of online learning programs. (Stone \&Cathy,2019).In this connection, the study conducted by Khalid (2020), has proven the treasured and genuine shreds of evidence about the views of the students as well as of the various faculty members. "A learner there at Institute of Business Administration (IBA)Punjab University, told reporters, "although internetbased sessions presented mostly through video streaming devices are not always effective process of education, at least our duration isn't really going to waste and now we can complete the course. I keep hoping that this is a milestone forward though, from which we can take lessons, we can educate from the shortcomings and educational technology allow us in some areas of our projects. Some students were found satisfied with the recorded lectures and instructions uploaded to the internet rather than real-time online classes. Another student said that, even though remote learning is not as successful as a formal teaching-learning process at the moment, but it will be a turning point for all the students, and all students can get education from their shortcomings" (Khalid,2020).

\subsection{Cons of Online Learning}

Recent reports indicate weaker success rates for online courses relative to face-to-face instruction, but there is little evidence of blended learning courses incorporating these types of instruction(Stone,2019).Evidence suggests that E-learning has always been about comprehension and other higher-order purposes than just information preservation (Ritchhart, Church \& Morrison, 2011).Besides, technical problems pose an obstacle for E-learning. Complications frustrate the online learners and the instructors, so such issues will bother students towards their courses. The students also have to devote time to solving technological problems (Dumford \& Miller 2018). Besides, online modules, just as they include others, will alienate some students. Electronic classes require learners to follow greater initiative and responsibility and transform it from inactive to facilitating learning. However, learners who are accustomed to the traditional environment in schools, this can be difficult for them (Jacob, \& Radhai, 2016). 
Moreover, functioning and access to E-learning through computer, android devices, and the presence of an effective teaching-learning process varies among students and this is a major problem with E-learning. the radical shift to online teaching can also cause anxiety in students. Many approaches have arisen to enhance delivery of the online classes. Obvious problems like inadequate integration, lack of expertise, or technological malfunctions must first be resolved ("The Rise of Online Classes after COVID-19: Best Practices Based on Literature", 2020).

Likewise, another case study in Pakistan provides evidences regarding the perception of students who were found having no internet facilities. Especially in the remote areas of Pakistan, students were found having insufficient internet and other facilities.

Table 1 Cons of Online Learning in views of some Faculty Members and Students

\begin{tabular}{|c|c|c|}
\hline $\begin{array}{c}\text { Author \& } \\
\text { Year }\end{array}$ & Views of the Faculty Members & Views of the Students \\
\hline $\begin{array}{l}\text { Khalid } \\
(2020)\end{array}$ & $\begin{array}{l}\text { Member of the Karakoram International University } \\
\text { (KIU) student affairs said "almost all students in } \\
\text { Gilgit Baltistan also don't have internet access, a } \\
\text { desktop pc or cellular phones and are entirely cut } \\
\text { off of the university." } \\
\text { Most educators have been saddened by the students } \\
\text { ' negative response. } \\
\text { Another chairman also voiced for the impact of } \\
\text { online classes and the capacity building of the } \\
\text { faculty. } \\
\text { A young lecturer also illustrates as "We are at a } \\
\text { pandemic worldwide. We 're all trapped in the } \\
\text { building. Universities can't expect students to } \\
\text { display the same excitement in quarantine, the } \\
\text { students are also part of a generation commonly } \\
\text { suffering from anxiety, depression, and lack of } \\
\text { mental well-being." } \\
\text { The lecturer clarified that she found some } \\
\text { unreasonable issue related online system because in } \\
\text { Pakistan we can see the majority of students are } \\
\text { from the areas where there is no electricity or } \\
\text { internet facilities. She further stated that all her } \\
\text { efforts were in vain due to such issues. }\end{array}$ & $\begin{array}{l}\text { "We Oppose Online Classes" online learners were } \\
\text { found re-tweeted about the online education } \\
\text { injustices. } \\
\text { They shared their views about obsolete marking } \\
\text { systems and asked for research". } \\
\text { "A student of fine arts at the University of } \\
\text { Information Technology, Engineering \& } \\
\text { Management Sciences (BUITEMS) said that most } \\
\text { of her courses, such as printmaking, painting, and } \\
\text { drawing from real life, cannot be taught effectively } \\
\text { through online classes". } \\
\text { "A student of mass communications said that her } \\
\text { courses in media and radio production required } \\
\text { access to equipment she had no access to in her } \\
\text { city". } \\
\text { Another student said," the teachers worked } \\
\text { diligently to make the students shift to a new style } \\
\text { of learning, but some students are making it harder } \\
\text { due to their behavior She said almost the same } \\
\text { students who subsequently break rules, carry a } \\
\text { tune or make strange noises make bloggers to } \\
\text { interrupt lectures online". } \\
\text { A Mass Communication student said, "Since the } \\
\text { internet is not working and the speed is not } \\
\text { adequate to allow video conferencing with her } \\
\text { teachers and classmates, she could not take a single } \\
\text { class. } \\
\text { "Some results were found in which students } \\
\text { demonstrated a lack of enthusiasm in taking } \\
\text { classes from home". }\end{array}$ \\
\hline
\end{tabular}




\begin{tabular}{|l|l|l|}
\hline $\begin{array}{l}\text { Adana } \begin{array}{l}\text { Anwer, } \\
(2020)\end{array} \\
\text { \& }\end{array}$ & $\begin{array}{l}\text { A case study was conducted which find out the } \\
\text { perceptions of higher level students regarding } \\
\text { online learning system in Pakistan .This study } \\
\text { reported the positive attitude of the student.73\% } \\
\text { were found satisfied about internet availability } \\
\text { while } 71.4 \% \text { learners were found satisfied } \\
\text { regarding using internet. }\end{array}$ \\
\hline $\begin{array}{l}\text { Mahmood, } \\
(2020)\end{array}$ & $\begin{array}{l}\text { Another case study was carried out which find out } \\
\text { the positive attitude of some students towards } \\
\text { online teaching learning system. }\end{array}$ \\
\hline
\end{tabular}

\subsection{The Role of HEC in the Improvement of Online Learning}

HEC assists all the higher educational institutions through providing and setting up digital facilities, conducting valuable training programs for guidance, and different modes for placing data as well as assessment strategies. There is no questioning the position of the Higher Education Commission as the cornerstone and financial backer of many funded researches taking place in the country. The HEC's Rapid Research Initiative (RPI) is one of those methods designed to meet the country's urgent needs. The HEC has also applied its online teaching guidelines for the universities and these are available on the HEC website. However, the modus operandi for conducting and orchestrating research remotely has still to be formulated. The commission has commenced to send letters to universities in a proposal to put more pressure on them and force them to initiate online campuses teachings as quickly as possible (Rizwi,2020).

The HEC has instructed to all universities to use the learning management systems to start online classes according to the notification given to all registered higher education institutions in Pakistan. They offer much higher that institutes having scarce infrastructure to initiate online classes should prepare to get up-to-date technology and train staff as a matter of urgency without sacrificing education. HEC announced earlier on March 18 that he had established an online course database and shared it with universities, as well as asking universities to plan courses for student dissemination ("Pakistani Universities asked to start online classes amid COVID-19 spread Xinhua | English. News Cn", 2020).

HEC has taken various initiatives to ensure that the students provide quality education during the closure, forming a Technical Support Committee (TSC) to help the employees at universities transition to the online educational style, established national Knowledge Bank (NKB) aimed at providing students and teachers with access to a wide range of academic resources ("HEC orders all universities to begin online classes", 2020).In an interview on 18 March, HEC Chairman 
said that no agreement had been reached on studies despite the country's closed circumstance toward corona virus COVID-19. It doesn't mean that classes will be suspended. "The teachers will give online courses during these three weeks" (Khushik, 2020).

Three alternatives options were also provided by the HEC and all the universities were guided to choose the option which is appropriate for their system. The first approach was to form an ad hoc committee consisting of faculty deans and led by the university's vice-chancellor. The other proposed alternative suggested setting up a part-time or temporary academic council, while the third choice was to appoint the universities' current academic councils as their online academic councils (Rizwi, 2020). Likewise, HEC completely endorses the requirement, both for online and conventional courses. As far as connectivity has concern, the HEC has proposed a 4-point connectivity program:

(a) Taleem Package for facilitating students in taking online courses

(b) Distribution methods for fulfilling the needs of the students consisting of various modes (HEC, 2020).

(c) Offline mode - distributing the recorded lectures in CD or other storage device and courier these materials to students.

(d) Student Facilitation Committees (SFC) university will establish SFC to address connectivity issues for remote area students.

The Higher Education Commission (HEC) has instructed universities to start online classes for the students and complete the current semester course work. HEC has also instructed universities to conduct their exams soon. The HEC devised a strategy for conducting quizzes, assignments, and tests from the students (HEC, 2020).

\subsection{Hope for the Best/Suggestions}

Written Documents and working together. Khalid (2020) quoted observations of the member of the student affairs at Karakoram University that when the situation persists and there's little change in online connection for classes so uploading the written documents can save their time which causes their difficulties. They said while the program is flawed, working together will strengthen it. Likewise, Another Professor proposed that the best choice is to upload the study materials. 
Recorded Materials. Some students suggested that documented lectures and directions posted on the web became significantly better for connection over electronic courses in real-time. Users even proposed projects and activities for the uploads (Khalid, 2020).

Digital specific course design. Educators indicated in the latest report of Australian universities that perhaps the consistency of tutorials most of which were simply transmitted to digital form wasn't even adequate to influence the participants. Teachers may use tools like Interactive Video to solve these issues to make their lectures more engaging online (Stone, 2019).

HEC Check on the online system. HEC Chairman Tariq Banuri announced the commission would Quantify the internet-based education programs, the efficiency of curricula, and the internet readiness of the instructors. Universities that fail to reach the requirements must cease their online activities until they can modify (Khalid, 2020).

Utilize face-to-face interactions when possible. Face-to-face interaction does not always include teaching, but may provide teacher help Whether they use Skype or Zoom in the form of a video call. Research has shown about millennial students that they want a satisfaction with being appreciated by their teachers, so this experience will significantly boost their confidence (Miller \& Mills, 2019).

Empathy, Enthusiasm, and Reflection on the part of the Teachers. One of the students encouraged that "In this tough time, teachers to be reflective, enthusiastic and empathetic, as an external motivator was the communication which learners used to have in the field. Even though it is difficult to get involved in online classes, teachers may either that their curriculum be flexible mostly to the environment (Khalid, 2020).

Supported Engagement is Crucial. Daily and positive contact respectively teachers and learners usually enhance the online learning experience. Hence it is called Collaboration Sponsored. Indeed, a new survey showed that somehow the clarity and punctuality of lecturer input has been the most valuable sort of student-defined learning interaction (Ragusa \& Crampton, 2018). 
Differentiating online and face-to-face learning. Moreover, other students argued that "Teachers must consider that electronic or virtual tutoring is different from conventional face-toface classroom instruction. Besides learners at home, in their social circles, or rather encircled by their families, teachers ought to schedule class events" (Khalid, 2020).

Set Clear Expectations for Learning. Teachers need to set out reasonable goals for their pupils. Most learners will have no previous expertise to manage their workplace environment. For online courses, the disconnection can be even greater. Expectations like encouraging students to request daily formative assessments can help focus the resources of the students ("The Rise of Online Classes after COVID-19: Best Practices Based on Literature", 2020).

Low-budget and high-speed packages of internet. Government agencies such as the Higher education commission and the telecommunication Authority of Pakistan (PTA) have ordered telecommunication companies to continue providing internet connectivity to all the students on low-budget and with high-speed packages (Khalid, 2020).

\section{Principles for Online Classes}

Bao (2020) conducted a study onCOVID-19 and online teaching in higher education: A case study of Peking University, in which she described five key points with a high-impact and which are essential for E-Learning.

(a) high correlation between online education design and learning for students

(b) the successful distribution of instructional material online

(c) sufficient assistance for the students by staff and teaching assistants

(d) high-quality participation to improve student learning breadth and depth;

(e) contingency plan to address unforeseen online education network accidents (Bao, 2020). 


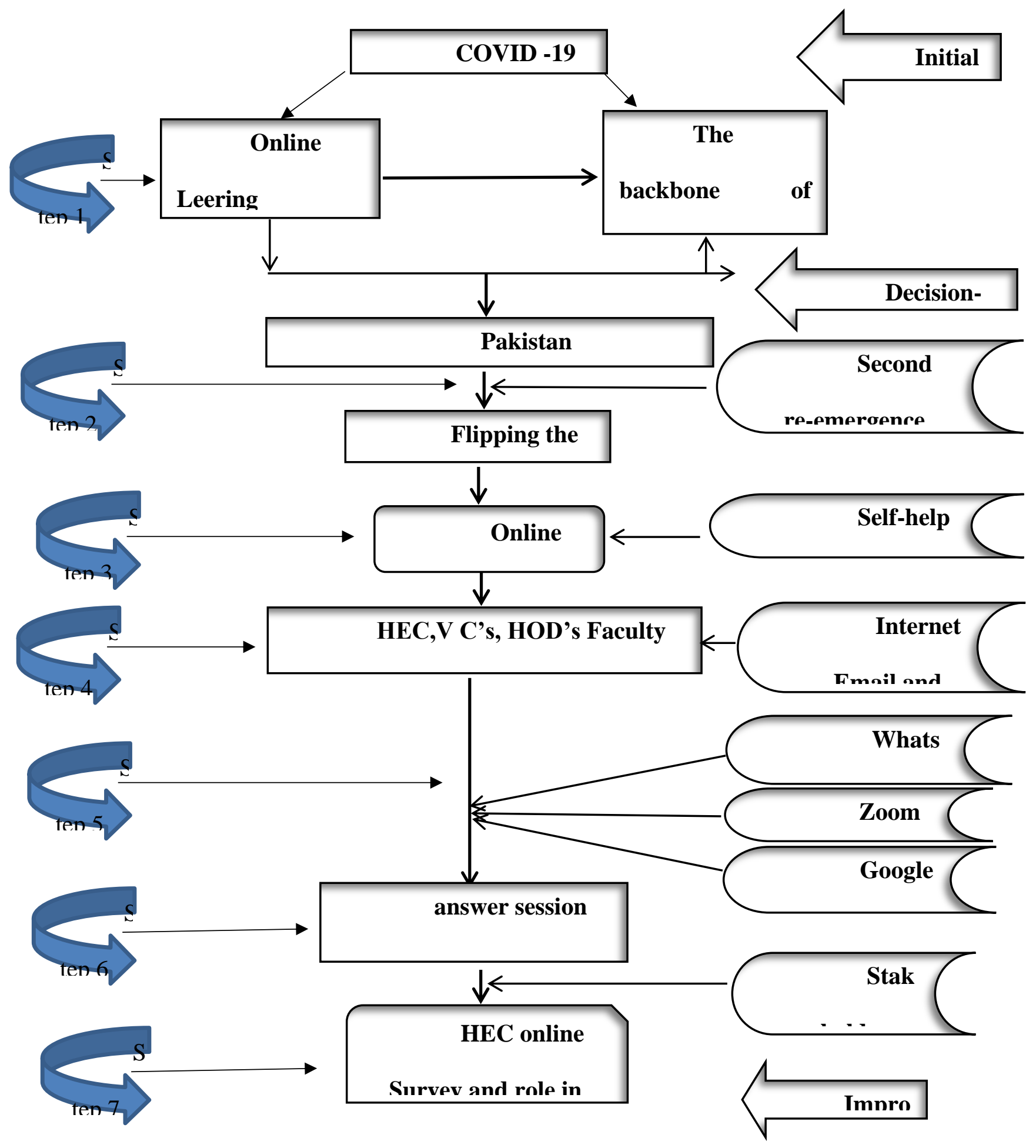

Figure 2 Theoretical Framework 


\section{Methodology}

The paper discussed various literature available on numerous sources. A review of the literature is an effective technique to produce scientific results to explain contextual-level evidence and focus on contexts so further study is required, a key element of the development of theoretical constructs, and following conceptual development (Snyder, 2019).It was a qualitative literaturebased study. Synder (2019) cited in Grant \&Booth, (2009) who described Qualitative literature as a method for comparing qualitative research findings.

\subsection{Sources for Data Collection}

Data were collected from the literature available online. Different articles, papers, reports, blogs, newspaper reports as well as official reports and news were carried out into consideration for this study. The researcher mainly focused on the authentic data from 2019-20 related to Pakistan. Besides the researcher studies the literature available for the previous COVID and Emergency during 2000.Furthermore, the researchers carried out into consideration other available data from the website which was closely related to the effects and recommendations for the recovery of the lost.

\subsection{Data Analysis}

The thematic method was used for categorization of the main themes from the literature related to the views of the students and faculty and the role of HEC in the improvement of the online teaching-learning process in Pakistan. Findings and conclusions were drawn based on the themes that emerged from the qualitative systematic literature review.

\section{Results of the Study}

The following results are drawn based on the literature related to COVID-19 and the gains /loss of the faculty members and students. Furthermore, suggestions of the faculty members and students as well as the role of HEC in the improvement of the online learning system in Pakistan.

\section{Theme I: Faculty and Students Optimistic Comebacks}




\section{Individual Comebacks}

- Enthusiastic to Make use of their resources. Faculty and the students' reports were found expectant. They were eager to make the use of their assets for the success of the online system which has been started due to COVID-19.

\section{Scholastic Results}

- Stay with the Education. Their reports were found passionate that they will endure with the education and no break will be transpired.

\section{Professional Responses}

- Contribution to the National Effort. Results were found brighter about their aspirations for the contribution to the National effort.

\section{Theme II: Students individual and scholastic Confident retorts}

- Online system is saving their time

Students' reports were found that their time is not deteriorating and the online system is equivalent to them. Further, their reports found demanding that internet connection can facilitate them to save their time. In this mode, they can be graduated on time.

\section{- Learning at Home}

The online system during COVID-19 was appreciated by the students and in their views, they might learn anything at home.

\section{- Step forward/turning stone/learning from mistakes}

Students statements were found more remarkable once they reported that through this system they can acquire from their mistake. as the use of technology is not a stress-free task. Moreover, internet connectivity, electricity problems can influence this learning. There are altered apps which are using for different programs. Accordingly knowing about all the apps and formerly expending such apps for learning activities is a trial and error method.

\section{- Satisfaction with the recorded lecture and instructions uploaded to the internet}

Students results were found contented that individually and scholastically they are acquiring education from the uploaded resources. such uploaded materials can be viewed at any time. 


\section{- Students get their Teachers working Delightedly}

This was found that students were blissful with their teachers working. They get their teachers to work delightedly for fluctuating their learning to an online system.

Theme III: Individual, scholastic and Professional loss of the Faculty

- Students were cut off from the University

Faculty members testified that due to lack of internet equipment they found some students entirely cut-off from the university online classes.

\section{- Distressed by the students}

Some faculty members as well as student reports were found discontented that the nonserious and undesirable attitude of some students has put them in tension. Such as making odd noises etc.

\section{Theme IV: Individual, scholastic and professional loss of the students}

\section{- Lack of access to online equipment}

The consequences of students lost were found unsatisfactory. Generally, students were from the zones wherever there was no internet access. Some students were facing the problems of the lack of smart mobile phones or computers/laptops for linking their online classes.

- Online system is insufficient for practical research

Student's descriptions were found attentive that the online system is not an adequate model for conducting practical research. Their reports additionally added that scientific research required lab work, as well as social science researchers, also demands for quantitative experimental work.

- Not fulfilling the needs of the fine arts students

Students from the departments of fine arts added that online classes are not suitable for printmaking, painting and drawing, etc.

\section{- Lack of enthusiasm}

Approximately student's reports were found unsatisfactory that due to the burden of work and home background they lack passion for fulfilling their online learning. 


\section{Theme V: Individual loss of the faculty and students}

\section{- Trapping in the building}

Faculty and student's results were found the same. Due to the outbreak of COVID-19, they were trapped in the building. Trapping was for safety measures but they lost individual gratification.

\section{- Lack of excitement}

Lack of excitement was reported on the part of the faculty members and students. Faculty member's reports were found that they are not expecting from the students to display their excitement. Moreover, students reported that environmental changes disturbed their excitement for learning.

\section{- Lack of Mental well-being}

Results were found that the faculty members and students agonized from anxiety and depression due to pandemic worldwide.

\section{Suggestions from the Faculty members for the improvement of online learning System}

\section{Theme VI: Capacity building and internet connectivity}

Faculty members deliver their knowledgeable suggestions for the improvement of the online learning system. They added that capacity building of the faculty and management cadre is the foremost demand which can improve the online learning system. Likewise, they added that internet connectivity may also be taken into account.

\section{Theme VII: Working together}

Results found that the accomplishment of the online learning system depends on working together. They added that everybody must do their responsibility in an integrated way.

\section{Theme VIII: Written Documents and uploaded Materials}

Faculty members also suggested that written documents and uploaded material can help students who are facing an internet connectivity issue. 


\section{Students Suggestions for the Improvement}

Theme VIII: Students Demands for

- Recoded materials, posted lectures and instructions

- Uploaded assignment and tasks

- Empathy, enthusiasm, and reflection on the part of the teachers

- Supported engagement

a. Daily and positive contact between teachers and students

- Differentiating online and face-to-face learning

a. Planning the class events in the comfort zones and surrounding their families

b. Adjustment of the workload according to students' needs

- Setting clear expectations for learning as some students have no know-how for using the technology as well as dis-connectivity is another issue.

- Issuing effective internet facilities for students so they can enjoy learning without disconnection.

Theme X: The Role of HEC

The following sub-themes were found on the part of the role of HEC for the improvement of the online system.

- Initiative steps

a. Sending letters to universities for starting online classes

b. Instruction for using the Learning Management System

c. Steps for ensuring quality education

- Setting up software and connectivity packages

- Technical support committee helping the university employees for online teaching style

- Conducting training programs

- Creation of data repository

- Establishment of national knowledge bank

- 4-point connectivity program

a. Taleem package for student's internet access

b. Distribution methods

i. To meet the needs of the students

ii. Shorter duration classes 
iii. Data-light options

iv. Synchronous and asynchronous modes (placement of all courses on the internet)

v. Offline mode (distribution of courses via CDs or other storage media.

- Guiding quality Enhancement

- Strategy for online teaching

- Setting up monitoring and assessment systems

\section{Conclusions}

It may be concluded that the outbreak of COVID-19 affects all the social and educational activities. Pakistan is a developing country faced this severe problem during March. All the educational institutions locked but the role of Faculty members, students, and HEC was concluded outstanding due to which online classes were made enlightened. This study was conducted for achieving the objectives, What the faculty members got individually, scholastically and professionally, what students got individually, scholastically and professionally, what are the suggestions of the faculty and students for improving the online learning system and what role frolicked by the HEC for the enlargement of the online learning system in Pakistan. The study achieved all the objectives based on the literature. Ten main themes were settled from the literature. The faculty members and student's role was concluded as enthusiastic for frisking their role at individual, educational, and national levels. The main problems were found about the internet connectivity and internet equipment due to which they were found cut off from the universities. Enthusiasm was not found due to environmental and home-related problems. The online system was found best for saving their time. Unity, internet connectivity, teacher's empathy, and setting learning goals were mainly suggested by the faculty members and students. The role of HEC was found the most outstanding.HEC provides every possible solution and equipment for the faculty and students. The study found more optimistic gains about faculty members, students, and HEC.

\subsection{Recommendations}

The students, faculty members, administration and the HEC are the main stakeholders to further strengthen the online education in HEIs. Despite of current COVID-19 situation, the quality of higher education should not be compromised. There are few recommendations based on this study: Firstly, HEC may implement their proposed policies with true sprits in all the educational institutions specifically located in relatively small cities. Secondly, Universities should make sure 
that faculty and students have sufficient digital resources to make their teaching learning smoothly. Thirdly, more training is required for faculty for effective use of Information and communications technology (ICT) for quality online education. Fourthly, as some people have anxiety of using digital tools, therefore, moral support, encouragements and following humanistic attitude may be more relevant for making this process successful. In addition, proper teaching methods and strategies may be taken which may further provide guidance to handle individual differences during pandemic situations. Moreover, universities should provide online access to their library. In this regard, a digital library is very effective approach. The six key components of online readiness discussed in this paper, should be rigorously checked and evaluated by experts. Finally, a follow up is more needed for the successful implantation of online teaching learning during closure of institutions.

\subsection{Conclusion}

This paper discussed the challenges and opportunities for faculty and students during the current pandemic situation by the sudden change of teaching and learning from on-campus to online. This paper explorer the role of HEC which is a regulatory body for HEIs in Pakistan, to implement the online learning effectively without compromising the quality of higher education in Pakistan. Finally this paper, proposed seven themes for efficient, quality and equal higher education to all students across Pakistan. Since this study was based on qualitative research paradigm, the future research may be conducted for large scale survey based questionnaire to get comprehensive data on how students and faculty perceive the online education. Furthermore, a survey type of research may be conducted to find out the more precise results from the prospective of faculty members and students. Moreover, a comparison of students' scores can be made between their on-campus and online learning. The future researcher can also develop a scale to measure online education readiness for students and faculty. 


\section{References}

Adnan, M., \& Anwar, K. (2020). Online learning amid the COVID-19 pandemic: Students' perspectives. Journal of Pedagogical Sociology and Psychology, 2(1), 46-49.

Bao, W. (2020). COVID -19 and online teaching in higher education: A case study of Peking University. Human Behavior and Emerging Technologies, 2(2), 113-115. https://doi.org/ 10.1002/hbe2.191.

Chen, Q., Liang, M., Li, Y., Guo, J., Fei, D., \& Wang, L. et al. (2020). Mental healthcare for medical staff in China during the COVID-19 outbreak. Retrieved 14 May2020.

HEC orders all universities to begin online classes. Pakistan Today. (2020). Retrieved 16 May 2020, from https://www.pakistantoday.com.pk/2020/03/30/hec-ordersuniversities-begin-online-classes/.

HEC (2020).HEC Announcements. Retrieved 16 May 2020, from Education.aspx.

Jacob, S., \&Radhai, S. (2016). Trends in ICT e-learning: Challenges and expectations. International Journal of Innovative Research \& Development, 5(2), 196-201.

Kahn, P., Everington, L., Kelm, K., Reid, I. \& Watkins, F., (2017). 'Understanding student engagement in online learning environments: the role of reflexivity', Education Liu, S.

Khalid, A. (2020). Are Pakistan's public universities prepared for online education?MITTechnology Review Pakistan. Retrieved 17 May 2020, fromhttp://www.technologyreview.pk/are-pakistans-public-universities-prepared- foronline-education/.

Khushik, I. (2020). Universities in Sindh yet to start online /Virtual classes. Daily Times. Retrieved 16 May 2020, from. https://dailytimes.com.pk/585227/universities-insindh-yet-to-start- online- virtual-classes/.

Mahmood S. Instructional Strategiesfor Online Teaching in COVID-19 Pandemic. Hum Behav \& Emerg Tech. 2020;1-5.https://doi.org/10.1002/hbe2.218.

Massan, S., Dahri, A., \& Shaikh, M. (2020). Effect of COVID-19 epidemic on research activity of researcher in Pakistan Engineering University and its solution via technology. $3 G$ Tecnología_Glosas De InnovaciónAplicadasa La Pyme, 249-263. https://doi.org/ 10.17993/3ctecno.2020.specialissue5.249-263.

Miller, A.C. \& Mills, B. (2019) 'If They Don't Care, I Don't Care': Millennial and Generation Z Students and the Impact of Faculty Caring', Journal of the Scholarship of Teaching and Learning, 19(4): 78-89.

Moore, C. \& Greenland, S. (2017). 'Employment-driven online student attrition and the assessment policy divide: An Australian open-access higher education perspective', Journal of Open, Flexible and Distance Learning 21(1): 52-62.

Nafees, M., \& Khan, F. (2020). Pakistan's-response-to-COVID-19-pandemic-and-efficacy-of quarantine-and-partial-lockdown-a-review. Electronic Journal of General Medicine, 17(6),https://doi.org/10.29333/ejgm/7951. 
Pakistani universities asked to start online classes amid COVID-19 spread - Xinhua | English.news.cn. Xinhuanet.com. (2020). Retrieved 16 May 2020, from http://www.xinhuanet.com/english/2020-03/31/c_138933150.htm.

Ragusa, A. T., \& Crampton, A. (2018). Sense of connection, identity, and academic success in distance education: Sociologically exploring online learning environments. Rural Society, 27(2): 125-142, pp.15.

Raoofi, A., Takian, A., Akbari Sari, A., Olyaeemanesh, A., Haghighi, H., \& Aarabi, M. (2020). COVID-19 Pandemic and Comparative Health Policy Learning in Iran. Archives of Iranian Medicine, 23(4), 220-234. $\quad$ https://doi.org/10.34172/aim.2020.02.

Ritchhart, R., Church, M., \& Morrison, K. (2011). Making thinking visible: How to promote engagement, understanding, and independence for all learners, San Francisco, CA: Jossey-Bass, pp.7.

Rizwi,S. (2020). Retrieved 16 May 2020, from https://tribune.com.pk/story/2220721/1- hecpressurises- varsities-start-online-classes/.

Snyder, H. (2019). Literature review as a research methodology: An overview and guidelines. Journal of Business Research, 104, 333-339. https://doi.org/10.1016/j.jbusres.2019.07.039.

Stone, Cathy (2019). 'Online learning in Australian higher education: Opportunities, challenges and transformations', Student Success 10(2): 1-11, p.2.

The Rise of Online Classes after COVID-19: Best Practices Based on Literature. (2020). [Blog]. Retrieved 22 April 2020, from https://feedbackfruits.com/blog/the-rise-ofonline-classes-after-COVID-19- best-practices-based-on-literature.

Yang, L., Zhang, C., Xiang, Y., Liu, Z., Hu, S., \& Zhang, B. (2020). Online mental health services in China during the COVID-19 outbreak. The Lancet Psychiatry, 7(4),https://doi.org/10.1016/s2215-0366(20)30077-8.

Zayapragassarazan, Z., \& Kumar, S. (2012). 'Active learning methods', NTTC Bulletin 19(1): 3-5. 